\title{
Matoš i Radić: dwie koncepcje kultury
}

\begin{abstract}
Falski Maciej, Matoš i Radić: dwie koncepcje kultury (Matoš and Radić: Two Concepts of Culture). „Poznańskie Studia Slawistyczne” 7. Poznań 2014. Publishing House Science and Innovate, pp. 91-106. ISBN 978-83-63795-79-5. ISSN 2084-3011.

Antun Gustav Matoš and Antun Radić were leading the Croatian intellectuals of their era. Radić, an ethnologist, formulated the concept of culture, in which the most important significance for the national identity was attributed to the people. He considered peasantry authentic and free of contaminations, accusing the elite of cosmopolitanism and abandoning of the Croatian source values. Meanwhile, for Matoš the most important factor in the Croatian culture was opening to the foreign influences and to their creative force. As a consequence, the opposition between the writer and the ethnologist appears, corresponding to the concept of open and closed culture. Despite the use of the same dichotomy of the elites and the people, each of them assigns different values of both cultural strata. Radic politicizes the peasantry and tries to bring it to the public sphere, pretending to defend the values of the indigenous Croatian culture, while Matoš, regardless of his political nationalism, creates the elitist vision of open and inclusive culture.
\end{abstract}

Keywords: Antun Gustav Matoš; Antun Radić; Croatian culture; authenticity; peasantry; Croatian elites

Antun Gustav Matoš był twórcą wpływowym, wychowawcą młodego pokolenia i intelektualistą par excellence, warto więc zastanowić się nad jego koncepcją kultury chorwackiej. Rekonstrukcja wyobrażeń związanych z fundamentalnym zagadnieniem definiowania kultury pozwoli odsłonić szerszy kontekst debaty tożsamościowej w Chorwacji i na obszarze południowosłowiańskim. Matoš bowiem wyjątkowo aktywnie uczestniczył w polemikach, reagował na rozmaite teksty i wystąpienia literackie czy naukowe, a uwagi dotyczące kultury rodzimej pojawiają się najczęściej w esejach będących odpowiedzią, atakiem bądź komentarzem. Formowały się niejako w dialogu z innymi, nabierając kształtu w wyobrażonej 
konfrontacji z odmiennym projektem ideowym. Tym bardziej więc uprawnione wydaje się zestawienie dwóch autorów, Antuna Gustava Matoša i Antuna Radicia.

Jeden jest rewersem drugiego. Ich znaczenie dla chorwackiej kultury i obecność w przestrzeni publicznej są podobne. Obaj zajmują się wieloma kwestiami: literaturą, językiem, historią, kulturą, polityką. Cechuje ich duża erudycja i obeznanie z nurtami epoki, a przede wszystkim zdolność do autorefleksji i pogłębionej analizy ideologicznej społeczeństwa. Obu też zależało na Chorwacji i właśnie Chorwacja była ich głównym tematem. Wszelako tam, gdzie Radić przyjmował stereotypową postawę uczestnika życia społecznego, Matoš wchodził w rolę outsidera. Pierwszy konsekwentnie budował karierę inteligenta poprzez studia z filologii klasycznej i slawistyki, doktorat w Wiedniu oraz pracę w chorwackich instytucjach kulturalnych i oświatowych, drugi natomiast kształcił się samodzielnie, z dala od oficjalnych ośrodków produkowania i rozpowszechniania wiedzy, poza obiegiem oficjalnym. Antun Radić brał czynny udział w życiu politycznym, sprawował mandat poselski i współzałożył partię chłopską, Matoš zaś pozostawał raczej z dala od sformalizowanych działań politycznych, mimo nieustannego komentowania tych zagadnień. Wreszcie: pierwszy systematyczne publikował rozprawy ugruntowane naukowo i zgodne z zasadami tworzenia tekstów akademickich, drugi zwykle nie przejmował się prawidłami dyskursu uczonego, respektując jedynie zasadę stylu.

W niniejszym artykule zajmę się przede wszystkim rekonstrukcją pojęcia kultury u Matoša. Koncepcja A. Radicia została już gruntownie opisana i zinterpretowana $\mathrm{w}$ różnych ujęciach, nie ma więc potrzeby jej ponownego szczegółowego opisywania (cf. Boban 1994; Čapo Žmegač 1997) i zostanie ona wykorzystana jako punkt odniesienia. Tymczasem dziełami autora Mòry zajmowali się przede wszystkim literaturoznawcy i językoznawcy, często oczywiście wzbogacający swoje podejście o elementy studiów kulturowych. Chciałbym zaproponować wstęp do zbudowania Matošowej definicji kultury. Wyczerpujące studium tego zagadnienia pozostanie do napisania i z pewnością przekroczy ramy artykułu, jednakże kontekst wpływowej i ,profesjonalnej” koncepcji Radicia ułatwi to wstępne rozpoznanie: Matoš-polemista najlepiej przecież wyrażał się w dialogu, nawet wyobrażonym. 


\section{Przeciwko ludowości}

Antun Radić nie tylko w najsłynniejszym tekście z 1897 roku, ale również w późniejszych pracach podkreślał, że źródłem autentycznej kultury chorwackiej jest lud (Radić 1897). W tym środowisku, opornym na przyjmowanie wpływów zewnętrznych, miałyby przetrwać elementy prawdziwej, oryginalnej kultury. Warstwy wyższe, elity, ulegały kosmopolityzacji przede wszystkim wskutek procesu kształcenia i towarzyszącej mu inkulturacji do ponadlokalnej sfery komunikacji i wyobrażeń. Innym powodem miała być specyfika chorwackiej sytuacji politycznej, skłaniającej warstwy uprzywilejowane do szukania porozumienia ze swoimi odpowiednikami na Węgrzech i w Austrii, w związku z czym, przejmując język niemiecki czy węgierski w miejsce rodzimego chorwackiego, traciły kontakt z lokalną ludnością. Źródeł przepaści między ludem a elitami Radić upatruje już w przyjęciu przez te ostatnie chrześcijaństwa i kultury łacińskiej, dwóch powiązanych czynników stwarzających, jak byśmy dziś powiedzieli, dwa kręgi wyobrażeń, dwie oddalające się od siebie wspólnoty komunikacyjne i wspólnoty praktyk. Wśród elit rodzimość musiała ustąpić pola uniwersalizmowi, język ojczysty - łacinie; w takim podejściu zrozumiałe jest przekonanie, że tylko lud mógł przechować elementy tego, co źródłowe, przedchrześcijańskie. Świat ludu chorwackiego tracił kontakt z warstwą internacjonalnych elit, czego zresztą nie można uznać za specyfikę chorwacką, lecz za trend typowy dla rozwarstwionych stanowo, feudalnych społeczeństw dawnej Europy. Ze względu na sytuację polityczną i agrarny charakter społeczeństwa Chorwacji, Dalmacji i Slawonii w XIX wieku, owo rozwarstwienie zmniejszało się powoli i z trudem, a proces narodotwórczy przebiegał opornie.

Zainteresowanie ludowością szło $\mathrm{w}$ parze $\mathrm{z}$ imperatywem stwarzania narodu i definiowania różnicy wobec Innego. Był to proces ogólnoeuropejski i Chorwacja nie stanowiła tu wyjątku. Przedmiotem przedstawienia był jednak lud wystylizowany, niejako dopasowany do wyobrażeń wykształconej elity. Mimo że podejście Radicia jest zupełnie inne - występował zdecydowanie przeciwko zniekształcaniu kultury ludowej, przeciw jej „upiększaniu”, będącemu odmianą kłamstwa kulturowego - z pokoleniem romantyków łączy go przekonanie, iż czyste źródła kultury narodowej biją na wsi. To właśnie kultura ludu miała być sferą wolną od zniekształceń, 
najmniej narażoną na wpływ, odporną na proces hybrydyzacji, osmozy, transferu wartości i praktyk kulturowych. Radić sądził, że w owym kulturowym konserwatyzmie tkwi wartość kultury wsi, a gruntowne przebadanie jej i opis mogłyby stanowić źródło odnowy moralnej całego narodu. Etnograf dzielił kulturę chorwacką na dwie opozycyjne sfery, elitarną i ludową, jednakże postulował dążenie do ich zbliżenia i ponowne ustanowienie narodowej jedności (cf. Rihtman Auguštin 1997). Radził wykorzystać w tym celu wartości ,źródłowe”, przechowywane przez lud i obecne w jego wyobrażeniach, wierzeniach i postawach. Ruch agrarystyczny i późniejsza polityczna aktywizacja wsi, która przerodziła się w ogólnonarodowy ruch, partię chłopską HSS (Hrvatska seljačka stranka) kierowaną przez brata Antuna - Stjepana Radicia, wyrasta właśnie z tych założeń ideowych. W czasach Matoša partia chłopska nie odgrywała jeszcze znaczącej roli politycznej, natomiast idee A. Radicia stały się ważnym punktem odniesienia, tym bardziej że on sam był wszechstronnym badaczem i działaczem kulturalnym oraz społecznym, związanym z najważniejszymi instytucjami narodowymi w Zagrzebiu.

Obok ideologii źródła i wyobrażenia czystości kulturowej, dominującego w etnograficznej perspektywie A. Radicia, pisarze moderny musieli się zmierzyć z drugą ideą związaną z przedstawieniem kultury wsi. Było to przekonanie o estetycznej wartości pieśni ludowych, zwłaszcza utworów epickich. Wykształcone elity odkryły dla siebie - dla kultury narodowej folklor w okresie romantyzmu. W obiegu ustnym zaczęto doszukiwać się śladów czystej, nieskażonej kultury, autentycznych wartości narodowych, ducha kultury lokalnej, przeciwstawianego negatywnie postrzeganej uniwersalności charakterystycznej dla poetyki klasycznej. W tej perspektywie kultura wsi stała się substratem różnicy, miejscem, skąd czerpano wyobrażenie źródła, tyle że przeniesionym na grunt estetyki. Nie sposób wprawdzie oddzielić sfery polityki od sztuki, ponieważ zbieranie pieśni i wzmożona działalność edytorska ogarnęła całą dziewiętnastowieczną Europę; każda nacja, a raczej jej elity, pragnęły mieć „swoje” pieśni, zwłaszcza epickie. Wśród badaczy folkloru południowosłowiańskiego trwało, doskonale opisane przez Rigelsa Halilego, oczekiwanie na ,południowosłowiańskiego Homera" (Halili 2012), epikę bohaterską zaś ustanowiono jako wzorzec doskonałości estetycznej i etycznej dla tradycji nie tylko serbskiej, ale szerzej, 
południowosłowiańskiej ${ }^{1}$. I to właśnie serbska epika stała się źródłem wielu inspiracji w okresie moderny, czego przykładem były choćby dramaty Ivo Vojnovicia. Za najdoskonalszy wyraz fascynacji estetycznym i etycznym aspektem epiki serbskiej można uznać wczesną sztukę Ivana Meštrovicia i jej apologię dokonaną przez Milana Marjanovicia (cf. Marjanović 1998).

Tak więc źródeł czystości kulturowej, autentyzmu, odrodzenia narodowego doszukiwano się w kulturze ludowej. Na genezę tego przekonania złożyły się rozmaite czynniki: romantyczno-narodowe pragnienie zdefiniowania odmienności wobec klasycznego wzorca, chorwackie dążenie do dowartościowania tradycji przemilczanej, właściwej większej części społeczeństwa, włączenie tradycji serbskiej w horyzont odniesień kulturowych, silna pozycja Serbii jako zwycięskiego państwa po wojnach bałkańskich. Na poziomie etycznym i politycznym swoiście pojmowana kultura ludowa staje się istotnym źródłem odniesień, w płaszczyźnie zaś estetyki, przynajmniej w jej wydaniu historyczno-normatywnym, miejsce to zajmuje pieśn epicka i obieg ustny, pomimo odmiennego przecież kanonu chorwackiego, odwołującego się do tradycji humanistycznych łacińskiej Europy.

Jak na tym tle wygląda koncepcja Matoša? Swoje poglądy przedstawia w wyrazisty sposób w eseju Narodna kultura z 1909 roku:

Klase koje treba tek kultivirati prikazuju nam se kao nekakva škola prave narodne kulture, kao naši učitelji (...). Narod, puk može više naučiti od nas no mi od njega. O kakvoj kulturi nema kod našeg seljaka na žalost još ni govora, a narodna poezija može biti dokaz za kulturnu sposobnost, ali ne i za kulturu narodsku (Matoš 1973a: 270).

Sądzę, że reprezentatywnie ujmują one reakcję autora na oba opisane wyżej trendy intelektualne w Chorwacji. W przeciwieństwie do Radicia, poeta uznaje chłopstwo za warstwę, którą „dopiero należy wykształcić”, uformować. Doszukiwanie się źródłowości czy autentyzmu w obiegu ludowym będzie mu obce. Trudno przypuszczać, by Matoš zgodził się na lokowanie „czystej duszy chorwackiej” właśnie na wsi, w środowisku najmniej dotkniętym procesami włączania w szersze kręgi wymiany, co przecież

1 Przykład kanonizacji epiki ludowej daje August Šenoa w poetologicznym wstępie do Antologii poezji chorwackiej i serbskiej z 1876 roku (Šenoa 1876: XXXV). Šenoa uważa, że epika ludowa w najlepszy sposób odzwierciedlała wartości kulturowe Słowian południowych - także Chorwatów. 
postulował Radić. Na czym oprzeć nowoczesną kulturę chorwacką? Na pewno nie na dziedzictwie ludu, podpowiada poeta, spierając się w tym punkcie $\mathrm{z}$ etnologiem.

Matoš w przywołanym tu eseju wyzyskuje źródłowe znaczenie słowa „kultura”. Czasownik kultivirati odnosi się w dyskursie naukowym do wykształcenia, formowania intelektualnego i społecznego, poddawania procesom uspołecznienia i nadawania ładu. Odnosi się także do pierwotnego znaczenia łacińskiego uprawiania roślin. Dotyczy zatem procesu wyłączania z natury i kształtowania na nowo, w pożytecznym czy też pożądanym celu. W tym samym fragmencie Matoš dopowiada: „Ima divljih, nekulturnih plemena sa divnom narodnom poezijom, i poznata je činjenica da dodirom sa kulturom iščezava narodna pjesma, jamačno iz prostog razloga jer je plod primitivnosti, barbarstva, a ne kulture" (Matoš 1973a: 270). Opozycja kulturowe - dzikie jest więc oczywista jako narzędzie nie tylko opisu, ale i wartościowania zjawisk społecznych. „Dzicy”, podobnie jak dziko rosnące rośliny, są jedynie materiałem na społeczeństwo, protokulturą. W tym rozumieniu chorwacka wieś to substrat, potencjalna część społeczeństwa, wykazująca predyspozycje do ,kultywowania”, a więc inkulturacji. Nie można jednak doszukiwać się w tej warstwie zasadniczych wartości narodowych, nie wolno wręcz stawiać jej za wzór czy upatrywać w niej esencji narodowej kultury, stoi bowiem w sprzeczności z kulturą w ogóle. Oratura, twórczość ludu, w perspektywie twórcy staje się jedynie oznaką dyspozycji kulturowej, a nie dowodem dojrzałości czy zmysłu artystycznego warstw ludowych, jak tego chcieli romantycy czy etnografowie tacy jak Stanko Vraz bądź Radić.

W chorwackiej etnologii szeroko komentuje się Radicia koncepcję dwóch kultur: elitarnej i ludowej (Rihtman Auguštin 1997; Čapo Žmegač 1994). Według jego historycznej interpretacji rozwój kultury chorwackiej przebiegał od pierwotnej jedności do rozpadu na dwie warstwy i dwie sfery, nazwane metaforycznie kulturą „rozumu” i „serca”. Celem badań etnologa byłoby doprowadzenie do ponownego spotkania i złączenia obu sfer, ponieważ ich rozdzielenie jest szkodliwe dla narodu i wystawia go zarówno na kulturową kolonizację bardziej dynamicznych sąsiadów, jak i grozi utratą autentycznych wartości narodowych, chorwackich. Warstwy wykształcone, opisywane przezeń jako wyobcowane, należałoby przywrócić narodowi. Radić, doktor nauk uformowany na uczelniach monarchii habsburskiej 
i działający w czołowych instytucjach naukowo-kulturalnych Chorwacji, nie ufał elitom.

Matoš bardzo jasno odnosi się do tego wyobrażenia. W cytowanym eseju bowiem pisze tak: „Seljak bi po toj logici imao biti glavni narodni kulturni faktor. Ne upuštajući se u dokaz apsurdnosti takvoga shvatanja, držim da je inteligent isto tako Hrvat kao njegov neinteligentni zemljak, a možda i mnogo više. Narod, puk, može više naučiti od nas no mi od njega" (Matoš 1973a: 270). Poszukiwanie esencji chorwackości wśród ludu uznaje za absurd. Wpisuje się w nurt podający w wątpliwość prymat ludowego, a tym samym serbskiego kanonu narodowego (także estetyki i etyki pieśni epickiej) w dziewiętnastowiecznej postaci. Matoš, jak wiadomo, ceni formę, podziwia poetów mistrzowsko dyscyplinujących słowo, takich jak Charles Baudelaire czy Francesco Petrarka. Dla niego literatura jest właściwie kolejnym aspektem „kultywowania”, okiełznania słów dzikich, mowy naturalnej, poprzez działania formalne. Literatura jest efektem pracy, kulturą. Inteligent również przynależy do sfery „kultywowanego”, czyli poddawanego obróbce i dyscyplinowaniu po to, by uczynić je lepszym. Wbrew romantycznej tradycji poeta odrzuca wyobrażenie mądrości ludowej, skrywanej gdzieś w ,duszy” czy „sercu” i przywraca autorytet wykształcenia oraz pracy nad sobą. To właśnie praca, wyrywanie człowieka - i narodu! - ze stanu natury miałoby świadczyć o włączeniu w obręb kultury. W horyzoncie Matoša wieś mieści się wciąż po stronie tego, co „,dzikie” (zapewne autor daje tu wyraz polemicznej przesadzie) i jedynie potencjalnie kulturowe.

\section{Pieśń ludowa}

Esej ma tę zaletę, że nie trzeba go opatrywać przypisami, a tezy nie wymagają długiego, popartego dowodami wywodu. A jednak często posiada ciężar równy rozprawie akademickiej, i tak bywa w przypadku szkiców Matoša. Narodna kultura to komentarz do najważniejszych pytań dotyczących kształtu kultury narodowej, jej wartości i celów, jakie stawia sobie społeczność zwana narodem. Autor zawarł w nim także swoje poglądy na oraturę. Współgrają one z tym, co sądził o kulturze ludu. Po pierwsze, poezja ludowa jest zróżnicowana i nie da się jej oceniać jednoznacznie jako dobrej czy wspaniałej. Matoš uważał, że podobnie jak w przypadku poezji 
artystycznej, piękne utwory są dziełami jednostek, „nieznanych poetów”: „Narod kao cjelina ništa nije stvorio" (Matoš 1973a: 270). Pogląd to zaskakująco nowoczesny. W tekstach dziewiętnastowiecznych badaczy wsi lud jawi się jako kolektywny twórca; nie dostrzegali oni indywidualnych realizacji utworów słownych, przypisując autorstwo tekstów, melodii, bajek itp. zbiorowości. Lud uznawano, tak jak to czynił Antun Radić, za skarbnicę dawnej kultury, kolektywnego strażnika przeszłości czy też czystości pierwotnego stanu społeczeństwa sprzed indywidualizacji. To, co indywidualne, nosi piętno jednostkowego konceptu, akcydentalności, natomiast dzieło kolektywu wydaje się stać po stronie tego, co konieczne, przez co byłoby „bardziej prawdziwe”. W nowszych rozważaniach nad folklorem uznaje się, że tekst pieśni i wykonanie są dziełem autorskim. Albert Lord i Milman Parry udowodnili, prowadząc długoletnie badania głównie w Sandżaku, że nie istnieje jeden tekst pieśni ani identyczne wykonanie. Poszczególne wersje mogą się znacznie różnić od siebie. Wykonania bywają wybitne, ale istnieją również zubożone czy niedoskonałe wersje „tego samego”, zdawałoby się, utworu. Matoš wyraża podobny sąd, przypisując udane realizacje jednostkom, które nie zostały uwiecznione czy zapamiętane przez zapisywaczy: „Narod nije spjevao narodne pjesme kao narod već kao nepoznati pojedinac, pa ima tek toliku vrijednost kolika mu je produktivnost boljih individualnih vrijednosti" (Matoš 1973b: 57). Sprawczość to zatem cecha jednostki, działającego człowieka, a nie zbiorowości. To ważny przekaz, ponieważ tkwi w nim ostrze krytyki wobec każdej potencjalnej ideologii masowej, także wobec nacjonalizmu (Matoš był jego zwolennikiem, ale rozważania nad pojmowaniem nacjonalizmu przez poetę wykraczają poza ramy niniejszego szkicu).

Poeta stoi jednoznacznie po stronie indywidualnej mocy twórczej. Jest rzecznikiem pokolenia, które domagało się „swobody tworzenia”, jak napisał w słynnym tekście Branimir Livadić. Pisano wówczas wiele o konieczności wyzwolenia się twórcy od nakazów społecznych, potrzeb politycznych czy imperatywu służby narodowi. Każda wypowiedź artystyczna jest komentarzem do kontekstu, w którym powstała; zasadniczą potrzebą modernistów była jednak wolność indywidualnego wyrazu. Co więcej, „narodnu kulturu ne stvara jedinstvo mišljenja nego snaga narodne energije i narodnog ideala" (Matoš 1973b: 57), kultura jest polifoniczna, bogactwem narodu jest wielość. Przekonanie o jednolitym, niezróżnicowanym 
ludzie-twórcy kłóci się z tym wyobrażeniem i Matoš zdecydowanie odrzuca możliwość uznania go za ideał kultury narodowej.

A.G.M. obala także ideę czystości kultury ludowej. Pisze, że główne motywy w każdej tradycji ludowej są takie same, powtarzają się. Każdy naród w warstwie ludowej przechowuje wątki aryjskie, indyjskie, płynące z praźródła kultur europejskich; niektórzy bohaterowie są obcy czy raczej niesłowiańscy; wiele motywów powstało w warstwie wyższej, wśród szlachty, i stamtąd trafiło do obiegu popularnego. Dlatego więc mówienie o czystości czy autentyzmie nie ma sensu w odniesieniu do ludu. Rzekome zamknięcie na wpływy to tylko pozór. Peter Burke wykazał przekonująco, że kultura ludowa ma złożoną strukturę, a jej pozorna statyczność wynika ze specyfiki rozprzestrzeniania się motywów, wzorów czy praktyk kulturowych w dawnych epokach przy ograniczonych możliwościach wymiany (Burke 2009). Ożywiony przez Carla Ginzburga młynarz Menocchio tylko z pozoru był prostaczkiem: Ginzburg odtwarza jego światopogląd i przypuszczalne lektury, a tropy w ten sposób wytyczone prowadzą do systemów wierzeń bliskowschodnich i przedchrześcijańskich. Złożoność warstw kulturowych i splatanie się wpływów będzie także zasadniczym rysem podejścia wypracowanego przez najbardziej wpływowego etnologa chorwackiego, Milovana Gavazziego. Doszukiwanie się czystości chorwackiej kultury w ludzie jest więc działaniem bezcelowym, a Matoš staje się tym samym rzecznikiem kulturowej otwartości, o czym będzie jeszcze mowa w dalszej części artykułu.

\section{Kultura zamknięta i otwarta}

W tekstach Antuna Radicia uwidacznia się zastanawiająca sprzeczność czy też co najmniej zderzenie dwóch przeciwstawnych tendencji. Etnograf-praktyk nie do końca zgadza się z etnologiem-teoretykiem kultury. Radić-etnograf postuluje synchroniczny opis kultury ludowej. Zawarty w pracy Osnova za sabirańe građe o narodnom životu kwestionariusz dotyczy rozmaitych aspektów aktualnego stanu badanej społeczności (Radić 1897). Radić proponuje wybrać dobrze określony teren, najlepiej gminę lub wieś, i sporządzić wielowymiarowy inwentarz, w którym znalazłyby się wiadomości zarówno o kulturze materialnej, jak i wierzeniach oraz stylu 
życia badanej społeczności. W obszernych wytycznych dla badaczy zawiera katalog wszystkiego, co można by opisać i co może mieć znaczenie dla zrozumienia całokształtu życia społecznego w danej grupie. Celem takiej zuniformizowanej praktyki miało być zestawienie cech kulturowych, które umożliwiłoby opis współczesnej Chorwacji. Radić wymaga, by badacz skrupulatnie wszytko zapisywał, nie zniekształcając danych i wyraźnie twierdził, że niepożądaną cechą jest jakiekolwiek nastawienie ideologiczne wobec wsi: ani lekceważenie, ani gloryfikowanie wsi nie służy obiektywnemu opisowi. Przypisywanie kulturze ludowej nadmiernie pozytywnych cech kłóci się z praktyką badawczą.

Tymczasem etnolog-teoretyk wyraźnie stawia wyżej kulturę ludu. Deklarując konieczność zintegrowania obu warstw społecznych przy zachowaniu pozytywnych aspektów każdej z nich, we wstępie do omawianego tekstu prezentuje głównie pozytywny obraz wsi i negatywny - elit. Radić, jak się wydaje, docenia przede wszystkim zamknięty charakter obiegu ludowego, wynikający z utrudnionej wymiany myślowej, kulturowej i powolnej dyfuzji praktyk między środowiskiem wiejskim na obszarze chorwackim a elitami i środowiskiem miejskim z jednej strony, innoetnicznymi sąsiadami zaś z drugiej. Właśnie dlatego zainteresował się tak mocno folklorem i życiem wieśniaków: zamknięte, a właściwie konserwatywne pod względem kulturowym środowisko miałoby w większym stopniu zachować rzekomą czystość kulturową niż społeczności miejskie, nie mówiąc już o sferze wykształconych. Trzeba przypomnieć, że poszukiwanie autentyczności napędzało działania samego Radicia i wiązało się ze sposobem myślenia o ugruntowanej już tradycji. Programowo nie włącza on miasta w horyzont badawczy, choć inna postawa byłaby anachroniczna. Miasto europejskie, zwłaszcza habsburskie, to tygiel, ośrodek życia i współbytowania członków rozmaitych grup etnicznych, którymi zarządzała administracja zdominowana przez język niemiecki, łacińskojęzyczny Kościół katolicki oraz wielojęzyczne elity polityczne i intelektualne. Tej mieszanki nie uważano za kulturę wartą analizowania: stanowiła środowisko naturalne badaczy, więc uważali ją za zrozumiałą. W kontraście do ośrodków takich jak Zagrzeb, Osijek czy Split, wielojęzycznych, zdradzających żywotność rozmaitych wpływów, kultura ludu jawiła się jako ostoja niezmienności i sfera, od której oczekiwano potwierdzenia źródłowych cech i wartości własnego narodu (cf. Boban 1979). Radiciowa wizja kultury chorwackiej zdradza tęsknotę za 
czystością, jednią; sposobem na jej osiągnięcie mogła być walka z tym, co uznawano za zewnętrzne, napływowe. I chociaż sam Antun Radić nie wyciągnął konsekwencji z tej postawy, działania i postulaty niektórych przywódców partii chłopskiej HSS z okresu międzywojennego wprost ujawniają taki cel: oczyszczenie kultury chorwackiej i wprowadzanie kulturowej autarkii (Leček 2006).

Matoš natomiast całą swą postawą manifestuje koncepcję kultury otwartej na wpływy. Wynika to z jego biografii: kilka lat mieszkał w Belgradzie, potem dłuższy czas w Paryżu; co więcej, jak zauważa Oraić Tolić, intertekstualność jego biografii uwidacznia się w trzech figurach, na które poeta się stylizował: członka bohemy, flanera i dandysa (Oraić Tolić 2006). Znajomość literatury i kultury Serbii oraz Francji czerpał z pierwszej ręki; uważał też niejako za swój obowiązek informowanie publiczności czytelniczej w Chorwacji o życiu kulturalnym i politycznym obu krajów. Co więcej: Matoš sądził, że kultura chorwacka będzie się rozwijać tylko wtedy, gdy twórczo będzie przyswajać najwybitniejsze dzieła europejskie, stąd cały szereg esejów poświęconych wybitnym i ówcześnie wpływowym pisarzom, takim jak Charles Baudelaire, Edgar Alan Poe, Auguste-Maurice Barres. W szkicu Umjetnost i nacionalizam bezpośrednio daje wyraz tej postawie, twierdząc że każda kultura narodowa powstaje i trwa w wyniku interakcji z innymi, a jej najwybitniejsze osiągnięcia zawsze rodzą się z twórczego przyswajania wpływów:

Baš zbog toga što svaka prvoklasna umjetnina, produkat uvijek naroda, može postati međunarodnim dobrom, nacionalizam umjetnički (usuprot nacionalizmu političkom) nije negacija tuđih vrijednosti. Naprotiv. Baš i bogatstvo i raznolikost narodnih posebnih kultura je pogodba za veliku simfoniju sveopćeg međunarodnog napretka (Matoš 1973b: 57).

Chociaż w sferze polityki opowiadał się za chorwackim interesem narodowym i nacjonalistycznym egoizmem, sztuka i kultura w ogóle pozostaje dla Matoša przestrzenią kontaktu i wzajemności. Fraza o wielkiej symfonii różnorodnych kultur mogłaby stać się mottem programów Unii Europejskiej; temat ten powraca u chorwackiego poety często, przede wszystkim w praktyce. Matoš uważał, że wybitni pisarze nie są „dobrem narodowym” i żaden naród nie ma do nich wyłącznych praw. Ich wielkość zasadza się 
na tym, że są czytani i popularni poza granicami swojej kultury narodowej: „Hegel je Nijemac, ali je koristio ruskom nacionalizmu, oplodvši kritiku Bjelinskoga i djelujući tako na stvaranje ruskog romana. Schopenhauer je Hrvat, jer je djelovao na shvatanje nekih naših pripovjedača" (Matoš 1973: 268). Ostatni cytat doskonale oddaje myśl Matoša: Schopenhauer jest Chorwatem pod względem przynależności do kręgu komunikacyjnego, podzielania podobnych wartości, wyobrażeń i symboli. Wybitni artyści tworzą, opracowując wielkie tematy kulturowe, tkwiące głęboko w samej istocie ludzkości i obecne w każdej tradycji lokalnej.

Matoš pisze wprost: „Originalne narodne poezije nema, kao što nema ni originalne ujmetne poezije" (Matoš 1973b: 59). Co więcej, uważa on też, że nie istnieje „czysta” sztuka narodowa, podobnie jak nie ma ,jednorodnych” narodów „czystych jak rasa” (Matoš 1973b: 58). Czystość w kulturze jest więc utopią. Jak sądzi Matoš jest to pogląd niezgodny z rzeczywistym rozwojem sztuki pojmowanej jako wyraz narodowego ducha i aktualizacja narodowej oraz ogólnoludzkiej potencjalności, jednak pogląd szkodliwy dla twórczości, ponieważ ogranicza możliwości artystyczne i sprowadza sztukę do funkcji służebnej wobec polityki. Chorwackość w sztuce to ,posebna nacionalna forma duha puna najevropskijeg sadržaja” (Matoš 1973b: 59). Inną kwestią jest kierunek i treść wpływów. W tej sprawie Matoš zdradza polityczne uprzedzenia: deprecjonuje sztukę wiedeńską i węgierską, ponieważ wywodzi się z ośrodków władzy kolonizującej Chorwację. Wyśmiewa twórczość czeską, gdyż Praga stała się dlań metonimią odrzucanego przezeń ruchu słowiańskiego. Preferuje kultury romańskie, stanowiące antidotum na wpływy niemieckie. Pomimo politycznej niezgody na współpracę z Serbami i obawy przed dominacją Serbii w regionie, docenia jednak i pozytywnie przedstawia osiągnięcia współczesnej sztuki serbskiej, często stawiając ją wyżej niż chorwacką. Autentyczność przypisuje wyłącznie formie i językowi jako wyznacznikowi odrębności; stąd wynika tak wielka rola przyznawana poprawności, kwestiom stylistyki i pracy nad językiem dzieła literackiego. Matoš staje więc na przeciwległym biegunie wobec Radicia i jego poszukiwania czystości. Bliżej mu raczej do Gavazziego, który wskazywał na świadomość tożsamości jako czynnik świadczący o odrębności kulturowej Chorwatów pomimo złożonej struktury wpływów, składających się na ich materialne i niematerialne dziedzictwo. 


\section{Lud i elity}

Równoległe czytanie Radicia i Matoša wzbogaca interpretację koncepcji obu autorów. Zestawienie pisarza i etnologa pokazuje, że Matoš porusza się w ramach dość spójnego wyobrażenia kultury narodowej. Wiąże się ono z jego przekonaniem o społecznej roli jednostek wybitnych, utalentowanych; z pierwszeństwem przypisywanym sztuce jako uprzywilejowanej działalności człowieka; z przywiązywaniem wagi do wykształcenia, pozwalającego na rozszerzenie horyzontów i zdolności jednostki, pojmowanego zatem raczej jako dyscyplina umysłu, Bildung, a nie zdobywanie praktycznej wiedzy. Pomimo deklarowanego po wielokroć nacjonalizmu, Matoš opowiada się za modelem kultury otwartej. Zewnętrzne wpływy postrzega jako wzbogacające, przyczyniające się do rozwoju. Sztuka, działalność intelektualna w ogóle, to dla niego dialog; jeżeli pisze o wyrażaniu się ducha narodowego czy potencjale tkwiącym w narodzie chorwackim, to pod wpływem kontaktu z Innymi. W szkicu Narodna kultura pisał: „Tuđa kultura je najbolji dio hrvatske savremene kulture, i kao ostali narodi mi možemo svoju kulturu stvoriti samo uportebom tuđih kulturnih elemenata" (Matoš 1973a: 269). W ostatecznym rachunku Europa jawi się pisarzowi jako wspólna przestrzeń symboliczna, a jeżeli można mówić o jakimkolwiek źródle, to najwyżej o indoeuropejskich korzeniach języków i mitów, tworzących wspólne dziedzictwo kulturowe.

Taka postawa zdradza akceptację dla dychotomii dzielącej społeczeństwo na elity intelektualne i lud. Według tej koncepcji elity stanowią doskonalszy, czy raczej pełniejszy, wyraz narodu: „Umjetnik može biti narodniji od svog naroda" (Matoš 1973b: 57); artysta lepiej wyraża cechy i charakter kultury narodowej, ponieważ potrafi nadać im formę i wejść głębiej pod powierzchnię zjawisk. Elity stanowią o kształcie tradycji, one decydują o polityce i ponoszą odpowiedzialność za rozwój bądź stagnację całej wspólnoty, dlatego Matoš tyle energii poświęca na krytykowanie postaw chorwackich intelektualistów i polityków, zarzuca im małostkowość, drobnomieszczański charakter, a ograniczenie horyzontów uważa za główny hamulec rozwoju narodowego. Od wyobraźni elit, chciałoby się rzec, i ich potencjału zależy los całego narodu, z tej racji, warto to powtórzyć, tak ważne jest kształcenie i stąd bierze się tak wysokie miejsce przypisywane sztuce i literaturze. 
Dla obu chorwackich autorów podział elity - lud, wysokie - niskie, ma zasadnicze znaczenie: to opozycja, która buduje strukturę pola społecznego i wyznacza zarówno miejsce grupy, jak i jej zadania oraz znaczenie dla całości społeczeństwa. Omawiani autorzy odmiennie przypisują znak pozytywny i negatywny, a różnica ma charakter polityczny. Matoš uznaje elity za warstwę, która powinna przewodzić, ma szczególną rolę do spełnienia, jest nosicielem etyki otwartości, odpowiadając za włączenie Chorwacji w szeroki obieg wymian kulturowych. Tymczasem Radić, rozczarowany postawą elit politycznych, dąży do włączenia chłopstwa w sferę publiczną i uczynienia go częścią narodu politycznego. Odrzucenie dotychczasowego modelu - dominacji warstw uprzywilejowanych - oznacza wielką przemianę postrzegania rzeczywistości społecznej oraz odwróceniem hierarchii. Idealizacja wsi wiąże się jednak z akcentowaniem zamkniętego charakteru kultury rodzimej i odrzuceniem tego, co Matoš tak ceni. Paradoksalnie, ponieważ etnologia to nauka o Innym, autor pierwszej naukowej koncepcji etnologicznej w Chorwacji proponuje model ekskluzywistyczny. Antun Radić swoją koncepcją kładzie podwaliny pod ruch chłopski, który z takim rozmachem rozwinął jego brat Stjepan i który stał się siłą dominującą w Chorwacji: w latach 20. i 30. XX wieku on właśnie nadawał ton chorwackiej debacie publicznej, odpowiadając za radykalizację postaw narodowych wokół idei odrębności. Matoš, politycznie związany z prawaszami, okazał się rzecznikiem kulturowej otwartości.

\section{Literatura}

Boban B., 1979, Shvaćanja Antuna i Stjepana Radića o mjestu i ulozi seljaštva u gospodarskom, društvenom i političkom životu, ,Radovi Filozofskog fakulteta u Zagrebu. Zavod za hrvatsku povijest" vol. 12, s. 265-302.

Boban B., 1994, Rezultati dosadašnjih istraživanja o Antunu i Stjepanu Radiću, „Radovi Filozofskog fakulteta u Zagrebu. Zavod za hrvatsku povijest” vol. 27, s. 255-270.

Burke P., 2009, Kultura ludowa we wczesnonowożytnej Europie, przeł. R. Pucek, M. Szczubiałka, Warszawa.

Čapo Žmegač J., 1994, Two Scientific Paradigms in Croatian Ethnology. Antun Radić and Milovan Gavazzi, „Narodna umjetnost” nr 32, s. 25-38.

Čapo Žmegač J., 1997, Antun Radić i suvremena etnološka istraživanja, „Narodna umjetnost" nr 34, s. 9-33. 
Halili R., 2012, Naród i jego pieśni. Rzecz o oralności, piśmienności i epice ludowej wśród Albańczyków i Serbów, Warszawa.

Leček S., 2006, Selo i politika. Politizacija hrvatskog seljaštva 1918-1941, w: Hrvatska politka u XX. stoljeću, red. J. Hekman, s. 119-143.

Livadić B., 1972, Za slobodu stvaranja, w: M. Šicel, Programi i manifesti u hrvatskoj knijževnosti, Zagreb, s. 180-184.

Marjanović M., 1998, Ivan Meštrović, prorok i slava Jugoslavenstva, w: idem, Izabrana djela, red. V. Brešić, Zagreb.

Matoš A.G., 1973, Narodna kultura, w: idem, Sabrana djela, sv. 14, Vidici i putovi. Naši ljudi i krajevi, red. D. Tadijanović, Zagreb, s. 267-271.

Matoš A.G., 1973b, Umjetnost i nacionalizam, w: idem, Sabrana djela, sv. 6, Feljtoni, impresije, članci II, red. V. Flaker, Zagreb, s. 56-60.

Matoš A.G., 1973c, Književnici bez literature, w: idem, Sabrana djela. sv. 15, Feljtoni, impresije, članci I, red. V. Flaker, Zagreb, s. 86-87.

Matoš A.G., 1973d, Od Pariza do Beograda, w: idem, Sabrana djela, sv. 5, Pjesme. Pečalba, red. D. Tadijanović, Zagreb, s. 163-165.

Oraić Tolić D., 2006, Tipovi modernog subjekta. Muškarci sa ženskim rodnim crtama, w: Čovjek, prostor, vrijeme, red. Ž. Benčić, D. Fališevac, Zagreb, s. 291-324.

Radić A., 1897, Osnova za sabirańe građe o narodnom životu, „Zbornik za narodni život i običaje južnih Slavena", 2, Zagreb.

Rithman Auguštin D., 1997, Hipoteza Antuna Radića o dvije kulture i hrvatska etnologi$j a$, ,Narodna umjetnost” nr 34(2), s. 35-44.

Šenoa A., 1876, Antologija pjesničtva hrvatskoga i srpskoga narodnoga i umjetnoga. Sa uvodom o poetici, Zagreb. 
